\title{
"In a Dry Season" - A Police Procedural Novel by Peter Robinson
}

\author{
Sanmati Vijay Dhanawade ${ }^{1}$ \\ ${ }^{1}$ Department of English, Shivaji University, Kolhapur, Maharashtra, India \\ Correspondence: Sanmati Vijay Dhanawade, Department of English, Shivaji University, Kolhapur, Maharashtra, \\ India.
}

Received: February 13, 2021

Accepted: March 12, $2021 \quad$ Online Published: March 16, 2021

doi:10.5430/wjel.v11n1p24

URL: https://doi.org/10.5430/wjel.v11n1p24

\begin{abstract}
Genre fiction, also recognized as popular fiction is an umbrella term as it comprises various categories, varieties, and sub-types. On occasion, innovative writers have practiced in mingling these methods and generating an entirely dissimilar variety of categories. In general, genre fiction inclines to place plentiful significance on entertainment and, as a consequence, it leans towards to be more widespread with mass audiences. But currently, writers are lettering beyond mere meager amusement and they are commenting on various socio-cultural issues, resulting in their writing more realistic. Furthermore, various life real things and norms implied in their writing are constructing the entire genre form and all its types more noteworthy and vital. As accredited by literary jurisdiction following are some of the leading classifications as they are used in contemporary publication: Fantasy, Horror, Science fiction, Crime and Mystery Fiction etc. The kind Crime and Mystery Fiction also has various categories for example, Cozy, Hardboiled, The Inverted Detective Story, Police Procedural, etc. In the present paper, Canadian crime fiction writer Peter Robinson's novel In a Dry Season is studied in the light of this police procedural type of novel writing. The paper aspires to discover various police procedural features employed by the writer.
\end{abstract}

Keywords: novels, a police procedural, forensic science, detective, police force

\section{Introduction}

The rise of the novel can be traced in the 19th century as per the history of English literature. Since then this archetypal form of writing has flourished very well and has given birth to several varieties of writings. For instance - epistolary novel, picaresque novel, crime fiction, etc. Charles Darwin has precisely proclaimed earlier that "It is not the strongest of the species that survives, not the most intelligent that survives. It is the one that is the most adaptable to change." Likewise, the novel form has adopted the modifications in society and its people from time to time. This is the reason that varied kinds of forms are present and prospered besides still blossoming in the literary domain. The positive transformation is the foundation of the existence and attainment of the novel form.

'A genre is a particular type of literature, painting, music, film, or other art form which people consider as a class because it has special characteristics' as per the Collins dictionary. A genre is a category of literature, such as romantic, mystery, suspense, science fiction or horror. Each genre has its treaties. Romance, for example, focuses on romantic love between two people and often ends positively in uniting two lovers or families.

In the extensive and interesting list of types of novels, Police Procedural Novel is quite a new and famous form of writing. Police Procedural novel is also known as the Police or Cop Novel and can be labelled as a blooming type of Crime fiction. The presence of a police officer and police force in fiction is as deep-rooted as detective fiction. But until the period of World War II, the post-war era which was embroidered with utter modernization and urbanization resulting in civil chaos, no one funded due attention and importance towards the police department. Hitherto writers narrated police officers in their writing as a foil or subordinate characters to highlight the chief detective figure in their novel. Many characters used to have a kinship with the police department. But it is indeed tough to find full focus placed on the police department or any police officer in writings of the era.

With the rise of vices of the industrial revolution, post-war statuses, increasing urbanization and the budding sluggishness of mankind, it became highly indispensable to have a police force in society to preserve peace and harmony. In a short time, society started giving adequate attention to the police department. The common public 
sensed the requirement of giving importance to unappreciated workings accomplished by the police officers. After a long wait, authors of the era, correspondingly, fondled on giving due prominence to police officers in their works. Print media, television, etc. took prestige in projecting departmental generous activities in front of society. This profitable variation in crime fiction occupied its place in all over the literary realm. After the 1960s onwards Police Novel started flourishing in a wide way. This gave birth to different types of narrative techniques. The format, the type was different but the pivotal character that is police officer, the department, and inclusion of crime, criminal was the similar type. The main focus of the cop novel was and is on police and crime, upright things and proscribed happenings.

Largely, in such a form of the genre, it is presented that the detective is an associate of the police force. Therefore it is evident that the readers will read the extensive depictions of police force activities. Many of the times the central character works with a squad to reveal the secret, moreover, specialists from the several other arenas can make their entrances in the story. The protagonist of the novel retains rock-solid law-abiding vision and accomplishes the investigation procedure by following the police department's treaties.

This type of novel concentrates on police and criminals, but there are certain police procedures also on the prime line. The typical writers paid consideration to exemplify the exploratory practices of officers and departments. The typical crime preventive acts, its significance in society, the bravura of command and communique arrangements within the department, etc. also in the list, to consider in a serious manner. Progressively numerous scientific and technical things got implanted in this variety of novels. For example - DNA analysis, Dactyloscopy, Odontology, Anthropology. This is a constructive aptitude for modern science to the police department. With the assistance of modern scientific methods, apparatuses and procedures police officers can accomplish their responsibilities devoid of any life-threatening concerns or with little complications. This method of working has unquestionably succeeded in time-saving and energy saving dictums.

Noteworthy authors of this genre include Michael Dibdin, Elizabeth George, John Harvey, Reginald Hill, P. D. James, H. R. F. Keating, Val McDermid, William Mcllvanney, Robert Daley, Ridley Pearson, Patricia Cornwell, Dan Mahoney, McKinley Kantor, Joseph Wambaugh, Ed McBain, Ian Rankin, Peter Robinson, etc.

\section{Peter Robinson: Crime Fiction Novelist}

British born Canadian crime fiction writer Peter Robinson is eminent for his crime novels and has also published a large number of other novels and short stories. Furthermore, a few poems and articles are also on his account. His Inspector Banks series is renowned. This series of novels have been translated into fifteen diverse languages. He is a celebrated literary figure for his well-crafted and multifaceted plots. His minute observations and expertise in detailing are praiseworthy; it succors his extraordinary art of characterization.

Peter Robinson accomplished a B.A. Honours Degree in English Literature at the University of Leeds. After this, he immigrated to Canada, in 1974 and obtained M.A. Degree in English and Creative Writing at the University of Windsor. He achieved his doctorate from York University, Toronto. He sometimes teaches Crime writing at the University of Toronto's School of Continuing Studies.

Peter Robinson was felicitated by The Dagger in the Library (Golden Handcuffs in 1994-1996), an annual award was given by the British Crime Writers' Association. Additionally, he has acquired Martin Beck Award, Grand Prix de Littérature Policière - International Category, Edgar Award for the Best Short Story, Anthony Award for the Best Novel, Macavity Awards for Best Short Story, and Barry Award for Best Novel.

Robinson was invited to be a part of The Detection Club in 2006. The significant club was formed in the 1930s by British crime writers, including Agatha Christie. It is a high-status thing and a sort of felicitation for any author to be a member of this well-regarded club. Robinson is a respected fellow of following clubs International Association of Crime Writers, Crime Writers of Canada, Crime Writers' Association, and Mystery Writers of America.

The literary career of the writer overtly demonstrates that the novel carved by him is a crime fiction novel.

\section{Theme of Murder}

In the present research paper, the main concern is Peter Robinson's novel In a Dry Season, the tenth in the Inspector Banks series. The novel got published in 2000 by Macmillan publications at first. It has won the Anthony and Barry awards for best novel and was nominated for the Edgar, Hammett, Macavity and Arthur Ellis Awards. In 2001, it has 
also won France's Grand Prix de Literature Policière and Sweden's Martin Beck Award. It was honored as a New York Times notable book of 1999. The novel is much-admired as Robinson's best and has received immense popularity and commercial response.

In the present novel, Adam Kelly, a 13-year school-going boy found a skeleton buried in a dried-up reservoir built on the site of a ruined village while playing over there and notifies about skeleton to the police department. This Thornfield Reservoir was formed in the early fifties and previously it was identified as Hobb's End. Accordingly, readers do experience the era during fifties along with the wartime thrill. Two narrators narrate the story to recreate the past era in such a way that the reader starts living in that historic era. Over and over again readers are migrating from past to present and vice versa and try to connect the thread of the story. The story gives the impression of a typical homicide mystery blended with a couple of love stories, but the novel is stuffed with plentiful things in it to discover. In course of time, DCI Banks and his teammates discovered that the skeleton is of Gloria Shackleton formerly recognized as Gloria Stringer.

\section{Male Protagonist of Police Novels}

Peter Robinson has generated a fictional character entitled as DCI Alan Banks. Alan Banks holds the rank of Detective Chief Inspector in the Homicide and Major Crimes Department. As per convention of crime fiction writing, detective stories, police procedural genre, Peter Robinson has created Male Protagonist in his crime and mystery fiction series. With reference to four queens of crime fiction writing that is Agatha Christie, Dorothy Sayers, Ngaio Marsh, and Margery Allingham, one can straightforwardly conclude that Robinson has written his series abiding by the widely accepted decrees of crime fiction in the regard of formation of the Male Protagonist.

The central character of the novel DCI Alan Banks possesses a Higher National Diploma in Business Studies. He has undergone several police training courses. However, he has a sound knowledge of music. In addition, he is warmhearted towards literature so he keeps on reading various books. His observation ability is implausible. Nevertheless he does not look remarkably handsome but retains a striking personality which usually fascinates women.

A sense of balance between Professional and Personal Life of any police officer is the striking feature of that police persona. Keeping a good equilibrium and appropriate space between both things is essential. Alan Banks was married to Sandra. They have two children, a boy named Brian, who becomes a successful rock musician in future days and one girl called Tracy, who has good academics. Banks is a complete family man, beloved husband, and loving father. Whenever he has the time he always spends his time with his children. It is the unpleasant and uncovered truth that due to the overwork of the department, generally, officers do not find enough time to spend with their family. Often their family and acquaintances complain about their less involvement in family functions and societal programmes, the same case is with DCI Banks. He is always engrossed in his official work. Every so often he is considering family duties secondary. However, it is the quality of the protagonist of the story to retain an adequate balance between personal and professional life. Somehow the central character is capable of performing both the tasks at the same time.

\section{Use of Police Codes and Manners}

The present novel is brimming with usage of various police codes and manners. But the writing expertise of the writer has made the novel stress-free to comprehend for every reader of crime fiction. The writer has taken precautions while introducing new stuffs, procedures and techniques of the department and explained it in comprehensible manner to his booklovers. The idea of the Police department, its functioning scheme, its several divisions, numerous officers, their pecking order, is styled by the author in a diverse bravura with various characters and instances in his writing.

George N. Dove describes the police procedural as per two criteria; in his The Police Procedural, 'First, to be called a procedural, a novel must be a mystery story; and second, it must be one in which the mystery is solved by policemen using normal police routines' (47). George N. Dove has concentrated on customary puzzle-solving story with the assistance of evidence along with the significance of policemen and his procedurals.

The very elementary code of prefix and designation is observed by the writer in very easy tactic. Police officers who are members of the Criminal Investigation Department (CID) or Special Branch and certain other units who hold ranks up to and including Chief Superintendent can use the prefix Detective before their rank and name. These 
officers play a very vital role in the department. For efficient execution of their work, these associates are accompanied by departmental training and techniques. Detective prefix indicates their ability to investigate and work efficiently.

Typically, writer Peter Robinson is skillful in particularizing. He produces a live picture of any character or situation in his novel vividly. The minute observation, microscopic details, eloquent language of writing leads readers to imagine and live the scenes of the novel, and to consider as a character of the novel. This expertise of Peter Robinson has proven very accommodating and apropos to follow the fundamental prerequisite of Police procedural novel writing. This proficiency has assisted the writer in depicting typical police codes and manners to create his novels more concrete and real. Though readers are reading fiction still they are facing actual life, genuine police officers, their codes and manners, their lifestyle, realistic cases, and factual felons too.

\section{The Designation}

In any organization and any department ranks or designation do exist for the better execution of any small task or big mission besides to maintain balance and harmony among officers. This system is universal, although in each nation and department its structure and name are different. The whole phenomenon is vital for the smooth functioning of the department. In the present novel series, the writer has dexterously employed this phenomenon. The chief protagonist of the novel series and the protagonist of every novel is DCI Alan Banks. DCI stands for Detective Chief Inspector of the British Police force. DS Annie Cabbot is assisting DCI Banks in the present novel. Concerning Annie Cabbot, the initial DS stands for Detective Sergeant. A Detective Chief Superintendent is of high-rank compared to the ranks of Detective Chief Inspector and the Detective Superintendent. As per the departmental standards, the designation of The Detective Chief Superintendent is the utmost title in the CID, and functions as the senior detective and commanding officer. The contribution of Detective Superintendent Gristhorpe in solving the murder mystery of the novel has great importance. Chief Constable Jeremiah Riddle also makes his appearance in the present novel. In fact, Detective Chief Inspector Alan Banks got appointed on this case by Chief Constable Jeremiah Riddle to head the investigation of murder mystery of Gloria Shackleton.

\section{Police Uniform Protocols}

Another routine of the department is of not using uniforms regularly as cited in the present novel. Alan Banks is a casual dresser as he believes in simplicity. He distastes wearing a tie and if he has to wear one, he will tie it loosely and leave his top shirt button undone. In the present novel, when DCI Alan Banks went to inspect the crime scene for the first time, his colleague DS Annie Cabbot assumed him as a normal citizen, not as a police officer. This confusion happened cause of the casual dressing of Banks. At times Banks hilariously commits that he doesn't look like a DCI. At the moment in the novel, he is in his blue denim shirt open at the neck, with no tie, light tan trousers, and black wellington boots. At the same time, DS Annie Cabbot is also not following her official dress code. She was wearing blue jeans and a white blouse made of some silky material. Over the white blouse, she wore a herringbone jacket. Besides she had her black-rimmed sunglasses on.

When DCI Alan Banks and DS Annie Cabbot both went to London to take an official interview of Vivian Elmsley, sister-in-law of the victim, regarding the case, that time also both were in their respective civil garments. DCI Alan Banks wore a lightweight cotton summer suit and with it a red and grey tie, top shirt button undone. DS Annie Cabbot was looking very businesslike in a navy mid-length skirt and a silver-buttoned blazer over a white blouse. The duo was looking like normal civilians on their business excursion, not like typical police officers on their way of investigation of a murder case.

Readers can detect that the novelist himself has specified validation for the above-stated point, in the present novel. DCI Banks along with his colleague Annie Cabbot visited Bramley Town End, where Gwen and Matthew had lived, regarding Gloria's murder case. As the narrator narrates:

...Both were dressed casually; neither looked like a police officer. Sometimes, feelings against all forms of authority ran high on these estates. People spotted strangers quickly enough as it was, and they were naturally suspicious of anyone in a suit. Which was hardly surprising: on an estate like this, if you saw someone you knew wearing a suit, you assumed he had a court appearance coming up; and if you saw a stranger wearing one, it was either the cops or the social. 
Frequently, police work demands exploration and fieldwork. Officers need to interview people around the whole locality as per the need of the case. At times, they arrange interviews in public area for example café, hospitals, etc. At very single place and time they cannot explicitly demonstrate their real identity to everyone. Occasionally, they need to be secretive in search of the real felon. This is the reason that every time they cannot wear departmental uniforms and badges indicating their profession and rank. Throughout the whole novel, nobody is displaying any symbol, icons, and badges of the police department to indicate the identity as a police officer. Every police officer is dressed up like a civilian, very casually but decently. There is no deliberate exhibition of the police force, any special rights, reservations, hierarchy. It is beneficial to comprehend the reality of the crime scene at first hand. Due to this dressing modus operandi interviews and interrogations can be executed without any unnecessary departmental burden. Sudden visits and investigation, inspections can be performed without any annoyance. To capture the real felon without alarming is possible with the help of this manner of not demonstrating departmental icons publically.

\section{Around-the-Clock Police Profession}

The police officers' job is around-the-clock service. Whenever any officer gets a call from the department, society, or any help seeker person, a policeman needs to attend it without any delay and fault. Though the officer is on approved official leave, duty may demand him or her to rejoin the duty at any moment of the day. Then the police officer can't display any choice of his own. Especially, if the higher authority is calling then it becomes a critical circumstance. Identical incidents often happen with DCI Alan Banks. He is on approved holiday and spending his day in painting his house to reduce his loneliness compelled on him cause of his betrayed wife Sandra. Secondly, he is calamitous as his son Brian did not score decent grades in his university exam. Besides, his son is not feeling bad or remorseful about his meager scores, and on top of that, he is commanding his opinions on his father. DCI Banks is experiencing a lot of family drama and mental stress. Although any police officer is facing emotive uproar in his private life, he can't make that an excuse. In spite of emotional turmoil, he requests to complete his sanctioned work perfectly. He has to maintain a good amount of difference between his personal and professional life. He can't let his internal approaches hinder his departmental work. Similarly, DCI Banks is very competent in his work. He has mastered in maintaining fine equilibrium in his personal and professional life. Though he is upset by the family cataclysm, still he is answering the official phone call of his Chief Constable Jeremiah Riddle, right between his works, without any bitterness in mind, in the present novel. Peter Robinson's male protagonist Alan Banks holds the rank of Detective Chief Inspector in Homicide and Major Crimes Department as mentioned earlier, and this designation and rank do not allow him to ignore or procrastination of any task. In this way, he gets assigned to a new assignment though he is on approved leave.

\section{Police Team Work}

Earlier crime fiction writers used to focus only on one detective or one police officer. Later on, they started concentrating on police officer along with his assistant and team. The modernization created varied departments within one department. Hence readers are offered multiple departments like traffic, robbery, fraud, homicide, juvenile, public morals (prostitution and gambling), internal affairs, cyber police, public relations, crime laboratory, police artists, bomb squad, SWAT team, SOCO team, etc. It is the indication that crime, criminal and its detection is teamwork. In real life, police officers like normal human beings need some support to solve the mystery of any crime. In reality, no one is superman or supernatural being to work alone and solve the mystery just like that.

Like other former principal characters, DCI Alan Banks, the protagonist of the present novel series, is the leading investigator who preserves various good qualities in his persona. Alan Banks is a reputed police officer with a good police record as an honest and competent employee. He is a virtuous team leader and a good teammate also. He enjoys working in a team and as a leader of his squad, he knows how to and whom to assign any work to his colleagues so the work gets accomplish sooner and better. He has sound knowledge of his teammates regarding their work abilities. He observes development in his colleagues furthermore as per the progress at times he gives compliments to them. Often he takes breaks and meals with his colleagues. At that moment he doesn't bother about any higher or lower rank or designation. As per the police procedural genre, Alan Banks works with a team but still, he always casts an exclusive impression on readers. Every time compares to other officers he turns out as a different and more talented person.

In the present novel, DCI Banks is working with DS Annie Cabbot. At first, both are strangers to each other. But in course of time, the friendly nature of Banks paves the way to build good professional rapport between them. 
Throughout the whole novel, one can notice friendly dialogues of both of them and scenes scattered everywhere. DS Annie Cabbot proves a great helping hand to DCI Banks. Her assistance truly helped DCI Banks to resolve the case.

Along with DS Annie Cabbot, DCI Banks works with PC Cameron, PC Bridges, DS Hatchley and other police officers. All are working with each other with great respect. They are fulfilling their assigned work efficiently. In consequence, it benefits DCI Banks to find out the real felon. Along with this police team, DCI Banks is seeking guidance from Detective Superintendent Gristhorpe. It is Gristhorpe, who confirms DCI Banks that felon must be from the American Defense Department, after observing a button given to him by Banks. It is a significant suggestion to DCI Banks. It helped Banks to narrow down the list of suspects. Throughout the whole case, DCI Banks is following and undergoing strict instructions and observation of Chief Constable Jeremiah Riddle also.

\section{The Police Protocol of Taping off the Crime Scene}

Taping off the area where the crime has taken place is an important and very fundamental police code. It tends to protect other citizens from troubling the crime area and things around it innocently or mistakenly. It is a kind of protection of the area for further analysis. Passing reference of taping off the crime scene is mentioned in this novel wherein DCI Banks interrogates DS Annie Cabbot about taping off the crime area that is Thornfield Reservoir as he observes the area was not taped off.

In this way, the detective of the story is not the almighty, not like a superhuman being or super cop trying to resolve the case alone without any sort of assistance and attaining sweet fruits of victory. In the police novel, the writer is keeping his/her pivotal figure smart, intellectual, valiant, brave but still a normal human being. Like real-life situations, these officers are functioning in a team. They are providing instructions and following the received instructions with the same consciousness. This is the truth of the life and police department. It creates a realistic picture in front of readers. Consequently, fiction becomes a fact of life. One requests to accept it as it is real and not fantasy. Maybe the truthfulness and realistic view is one cause behind the popularity of police novels.

\section{Use of Forensic Science in Police Investigation}

In ancient and medieval times the process of detecting crime and criminal and the final penalization was grounded on mythology, so-called paranormal powers, royal dynasty and jury of the society. In short, no science or technology was involved in it. The probationary process was widely based on the confession of the suspect. The representative of both parties' defendant and the opponent would argue in front of the society and then the social order or panel would give a verdict as per their understanding and presented speeches. This entire procedure has broadly relied on the confession of the person and so-called witnesses. The authenticity of any person or situation was always with a question mark.

As time has progressed, science and technology have given many benedictions to mankind. As per the developed time, the department also received its up-gradation. The modification was essential to cope up with the malevolent side of man and society who also got preceded instead of deterioration. Criminals of the contemporary era are indulging in diverse types of criminalities with various means. They are also accustomed to new scientific technology. They have unconventional methods to accomplish their sinning determinations. Hence to struggle with misfortunes of the new era the police officer also has to be up-to-date and abreast. Writers of this genre have mastered the skills of presenting criminals and crime solver officers in a blow for blow way. Such kind of cut-throat situation adds more mysterious magic and magnitude to the story of the novel. It definitely attracts readers of the new time. This is also one reason for the immense popularity of the genre. The modern scientific advancement got inserted in the crime detection process. It saved time and energy of law followers to maintain peace and harmony in society. It is normal to have certain things included in police novels such as DNA analysis, fingerprints, blood and hair samples, though it is not a Science Fiction. These things are not that widespread or common for masses. But still, police novel writers are ardent to use such things in their writings for numerous motives. At first, it is the necessity of the subject as per the present era. Secondly, to add trustworthiness to the writing, it is an adequate apparatus for the new age. Thirdly, to furnish the requirement of inventiveness, mystery, and inquisitiveness of newfangled readers, it is very supportive. Above all, these innovative techniques are broadly acknowledged and recurrently used in the law and order sector, now a day. Hence it converts obvious for writers to illustrate such things, tools, and techniques in their writings. To add to this, readers of modern times have broadly acknowledged such things. Not only, these things got accepted but also got popularized greatly by the class of readers of the new time.

A Scenes of Crime Officer (SOCO) is an officer who collects forensic evidence for the British police. They are also Published by Sciedu Press 
referred to by some forces as Forensic Scene Investigators (FSIs), Crime Scene Investigators (CSIs) or Crime Scene Examiners (CSEs). SOCOs are usually not police officers but are hired by police services to help them with precise scientific data and evidences. This lineup gathers pieces of evidence with utter careful nature and gives collected concrete clues to the detectives of the Criminal Investigation Department and the forensic research laboratory. The SOCOs do not examine the crime or scrutinize proofs themselves. They can just accumulate it as they don't hold any authority to investigate on their own.

In the present novel, there are ample amount of instances of usage of modern scientific-technical apparatus, procedures, and departments to dazzle readers which makes novel reading more spellbinding.

In one scene of the novel, the writer has narrated that DCI Alan Banks is discussing the case with his colleague DS Annie Cabbot and updating her about the recent activities about the case. He informs her that he had called his sergeant and instructed him to organize a SOCO team to dig out the bones tomorrow morning. A person called John Webb will be in charge as he has studied archaeology. Besides, he has suggested their odontologist, Geoff Turner to have a look at the teeth of the skeleton as soon as it can be arranged. DCI Banks also suggested DS Annie Cabbot arrange a Forensic Anthropologist. In one single scene and dialogue, the pivotal figure has given references to multiple departments, varied branches of science. This is the need of the case, story, and new age also. Writers of new phases have mastered this skill of modern, scientific techniques.

\subsection{Forensic Anthropology}

Forensic Anthropology is the branch of Physical Anthropology, on a legal platform, usually for the recovery, identification, and documentation of skeletonized human remnants.

As per Adam Kelly's, a local boy, information police force initiated to investigate about the found skeleton. After investigation police department concluded that the skeleton was of Gloria Stringer and the crime must have happened more than fifty years ago. As per the instructions given by DCI Banks, DS Annie Cabbot, traced Dr. Ioan Williams, University of Leeds, a physical anthropologist with a fair bit of experience in forensic work.

The described discussion between Dr. Ioan Williams and DCI Banks is very technical. There are many references for scientific terms related to human anatomy for example - pubic, pelvic area, epiphyses, collar bone, clavicle, skull sutures, sagittal suture, endocranial closure, occipital and lambdoid sutures, skeletal anomalies, ligamentous tissue, etc. Moreover, there are references for some more techniques of science and technology - radiocarbon dating, carbonate testing, ultraviolet fluorescence test, histologic determination, Uhlenhut reaction, etc. At the end of the discussion, Dr. Ioan Williams indicated some marks on the skeleton's ribs and pelvic area. As a result, all concluded that the person got brutally stabbed which caused that person's demise. It is the microscopic observation, sound knowledge and firm concluding of Dr. Ioan Williams, confirmed that the skeleton is of a young girl, who got pierced bitterly numerous times and consequently passed away. The infinitesimal observation of Dr. Ioan Williams gave one more information about the girl that she must have given birth to a child only once in her lifetime. This is the amazing thing of science that the dry-dead skeleton is placing on a laboratory table without any living and concrete information but with the help of scientific techniques and observation, one can gather plentiful shreds of evidence about the owner of the skeleton. By observing the skeleton Dr. Ioan Williams anticipated that the victim had a physically healthy life. This is the strangest thing of science which can confirm the healthiness of a dead person.

\subsection{Forensic Pathology}

Dr. Glendenning an authorized departmental doctor, and top pathologists in the country added more information after inspecting the skeleton, of strangulation about the murder mystery. Dr. Glendenning provided information that the person got strangulated dreadfully and then perhaps got knifed pitilessly, to ratify the death of the person. Several strong and severe actions broke almost all vital body organs and that directed to the death of the person. Dr. Glendenning also added that he can ratify that the evildoer must have been a man, who was physically strong but became psychologically senseless and committed the homicide of a young girl in a very ruthless manner after pondering on strong marks on the skeleton.

\subsection{Forensic Odontology}

The entry and assistance of Geoff Turner, the Forensic Odontologist, is significant and precisely helpful to resolve the case in the present novel. He has provided valuable statistics to DCI Banks, regarding the victim. Forensic Odontology is the study of the distinctiveness of dentition, commonly known as the study of teeth. Geoff Turner calls 
DCI Banks and informs:

'... The third molars are up - that's wisdom teeth to you laymen - but the apexes haven't quite closed yet, nor have the medial sides of the incisal sutures. The third molars don't usually come up until your early twenties, so there's our first clue. Then the apexes are usually closed by the age of twenty-five and medials by thirty. Which makes her mid-twenties, give or take a year or two.' (111-112)

This information flow is full of technical jargon but still any common reader can understand it properly. This is the skilled writing of the writer Peter Robinson that in spite of the scientific terminology the discussion is easy to comprehend for everyone. It is a kind of up-gradation of common man's knowledge regarding Odontology, it seems. This is a good example that science can be of great help to the police department. With the help of the above-mentioned information, DCI Banks concluded that the victim was young, around 25 years old and got buried before the fifties. In this manner, Geoff Turner assisted DCI Banks to assume the timeframe of the victim's death and burial.

\subsection{Forensic Psychiatry}

Forensic Psychiatry is a specific branch of psychiatry which is applied to and grounded on scientific criminology. Peter Robinson has utilized this branch of scientific information in his writings throughout the Inspector Banks novel series. In the present novel also a writer has employed Forensic Psychiatry with the aid of the character named Dr. Jenny Fuller. DCI Banks is a good friend of Miss Fuller and she is a well-known lecturer in psychology and has experience of working in California and York University also. She has been on training courses with the FBI profilers. Her knowledge and plenty of experience in this field often extended a helping hand to the Eastvale police department.

DCI Alan Banks furnished Dr. Fuller with information of Matthew Shackleton, brother of renowned novel writer Vivian Elmsley and husband of murdered Gloria. He was caught by the Japanese and has spent a few years in their prison camps. He was pretty disturbed when he returned home. Finally, he ended up his life by committing suicide five years after the war. After listening to the sad story of Matthew Shackleton, Dr. Jenny Fuller rightly concluded about Matthew Shackleton in her peculiar psychological way. She exclaimed:

' $\ldots$ if your man had indeed been a prisoner of war under such terrible conditions, then he was probably suffering from some kind of post-traumatic stress disorder.' (342)

She further added that this post-traumatic stress disorder is caused by some severe natural or human atrocities. For example - rape, assault, kidnapping, military combat, floods, earthquakes, bombing, fires, etc. The symptoms are many and varied too like recurrent nightmares about the event, flashbacks and hallucinations are common.

DCI Banks is keen about the subject and existing topic hence in the flow of conversation he enquired about various case-related things. He questioned her about amnesia, so Dr. Fuller to clear doubts positively affirms in the following words:

'Yes, there's psychological memory loss sometimes. Believe me, most of the people who suffer from this would find the memory loss preferable to the persistent nightmares. But the problem is that strong feeling of detachment; estrangement and separation come with it. You can't even enjoy your lack of recollection of the horror. People who suffer from PTSDs often find it difficult to feel or accept love, they become alienated from society, from their families and loved ones, and they have an extremely diminished in concentrating, hypervigilance, depressive or panic disorders.'(343)

The above-stated dialogue indicates the ruthless side effects of war engraved on Matthew Shackleton. Because of the war, he has suffered a lot, physically and mentally also. Due to the mental imbalance, he was not at all happy and healthy individual like the past. He is not able to perform his duties as a good husband and brother. Above all, though the war was finished, a kind of war was still there in his mind and brain. This inner and personal war was not letting him live his life peacefully. Finally, he committed suicide as if he was tired of fighting in his internal war.

Dr. Jenny Fuller's opinions were very studious and technically true about Matthew. Readers can understand the lesson about war prevention and in case if someone is undergoing any mental trauma, that person needs special 
attention and guidance. The physical wounds, burns can get heal but the strikes got on the mind cannot get cured.

\section{Imprisonment of the Culprit}

The motto of any police investigation process is to determine the identity of the culprit along with its all details. In the present novel, with proper analysis DCI Banks and his team is successful in discovering the real culprit of the Gloria's death that is Edgar Konig. The concluding pages of the novel are contributed to describe the final confinement of the murderer and judicial maneuvers. Readers along with the detective came to know that the murderer has committed the similar type of crime for many times before. The judicial system took decision and he got imprisonment for fourteen years. The societal denial and protestation against the culprit is a remarkable thing. The news of his sudden death during imprisonment brought good news for society.

\section{Conclusion:}

In a true sense In a Dry Season is a police procedural novel as it has several references of police codes. Writer Peter Robinson has smoothly followed various police codes and manners while writing. The depiction of the police department and its activities are without any distortion throughout the novel. The writer has given varied references to forensic science which are necessary and real. All are contributing to resolving the case. This novel is a perfect blend of crime, investigation, detection, forensic science, and police codes which caters to the need for a mystery, innovation, novelty and realistic view of readers of a new time. The judicial verdict and societal denial of the culprit demonstrates that vice will be condemned in the end and every wrongdoer will receive his or her adequate punishment.

\section{References}

Charles, J. R., \& Lee, H. (2010). A Companion to Crime Fiction. UK: Blackwell Publishing Ltd. 2010

Dove, G. N. (1982). The Police Procedural. Bowling Green, OH: Popular Press, 1982.

Priestman, M. (ed.). (2003). The Cambridge Companion to Crime Fiction, USA, Cambridge University Press, New York, 2003. https://doi.org/10.1017/CCOL0521803993

Robinson, P. (2011). In a Dry Season. London: Pan Books, 2011.

Thomas, R. R. (2000). Detective Fiction and The Rise of Forensic Science. UK: Cambridge University Press. 2000.

\section{Webliography}

[1] https://www.anglotopia.net/british-entertainment/brit-tv/brit-telly-101-understanding-british-police-ranks-mystery -shows/

Accessed on 10/11/2013

[2] https://www.bl.uk/romantics-and-victorians/articles/the-creation-of-the-police-and-the-rise-of-detective-fiction Accessed on 10/11/2013

[3] https://www.bookbrowse.com/author_interviews/full/index.cfm/author_number/861/peter-robinson

Accessed on 10/11/2013

[4] https://www.britannica.com/art/detective-story-narrative-genre 10/11/2013

[5] https://www.collinsdictionary.com/dictionary/english/genre 11/12/2013

[6] https://www.crimesceneinvestigatoredu.org/what-is-forensic-science/ 02/01/2014

[7] https://www.goodreads.com/author/quotes/12793.Charles_Darwin 10/11/2013

[8] www.inspectorbanks.com 10/11/2013

[9] http://januarymagazine.com/profiles/probinson.html10/11/2013

[10] http://medical-dictionary.thefreedictionary.com/deoxyribonucleic+acid 05/02/2014

[11] https://www.police.uk/ 05/02/2014

[12] http://www.thecrimehouse.com 05/02/2014

[13] http://www.thrillingdetective.com/trivia/triv288.html 05/02/2014

[14] http://www.topmystery.com/authors/biography/Peter-Robinson/ 05/02/2014 
[15] https://en.wikipedia.org/wiki/DCI_Banks 06/02/2014

[16] https://en.wikipedia.org/wiki/Genre_fiction 06/02/2014

[17] https://en.wikipedia.org/wiki/Scenes_of_crime_officer 06/02/2014

\section{Copyrights}

Copyright for this article is retained by the author(s), with first publication rights granted to the journal.

This is an open-access article distributed under the terms and conditions of the Creative Commons Attribution license (http://creativecommons.org/licenses/by/4.0/). 